九州大学学術情報リポジトリ

Kyushu University Institutional Repository

Food Safety Perception and Consumption

Decision: A Positive Analysis on Individual's Consumer in Tianjin City

Wang, Zhigang

Institute of Economics, Faculty of Economics, National University, China

Yutaka, Tomoyuki

Fukuda, Susumu

Kai, Satoshi

https://doi.org/10.5109/4517

出版情報: 九州大学大学院農学研究院紀要. 47 (2)，pp.469-475，2003-02-01. Faculty of Agriculture, Kyushu University

バージョン :

権利関係 : 


\title{
Food Safety Perception and Consumption Decision: A Positive Analysis on Individuals' Consumer in Tianjin City
}

\author{
Zhigang WANG*, Tomoyuki YUTAKA, Susumu FUKUDA \\ and Satoshi KAI
}

\author{
Laboratory of Agricultural Marketing, Division of Industrial Organization of Agribusiness, \\ Department of Agricultural and Resource Economics, Faculty of Agriculture, \\ Kyushu University, Fukuoka 812-8581, Japan \\ (Received October 30, 2002 and accepted November 7, 2002)
}

\begin{abstract}
Using the data from a survey conducted among consumers in Tianjin City, this paper examines how the individual consumer attributes effects their food safety perception and consumption behavior. In this study, as the consumption decision model of food safety, a probit model is used to analyze the relations mentioned above. The evidence from the food safety market provides substantial support for the view that consumers have different reactions to food safety perception and consumption according to their attributes. As a result, the main significant variables affecting the food safety perception and consumption (ready-to- consumption), living environment, education level and income, are the primary determinants of food safety consumption. This conclusion suggests that it is necessary to remove thoroughly the discrimination between cities and villages, to share an equal right to receive education, and to establish a rational and fair income distribution system in China, in order to enhance the consumers' comprehension of food safety and promote individual consumers' welfare.
\end{abstract}

\section{INTRODUCTION}

The social and economic structure of China has changed greatly since the economic reform and opening-up from 1978. The planned economy system of high centralization is more and more replaced by the market economy. The gross production value and the employment in industrial and commercial departments are rapidly increasing, and the production ability in agricultural departments is greatly strengthened. At the same time, the people's consumption level in urban and rural areas is continuously increasing; the demand for food is increasing and becoming diverse. Consumers' attention is turning from pursuing food quantity to pursuing food quality, safety, and health.

To adapt to this trend, the structure of the agriculture is being adjusted and changed, and at the same time, the food production and processing is being strengthened. The government continuously establishes series of standards and detailed regulations on food safety quality, safety and health.

With this background, how the food production and processing can adapt to the increasing change of consumers' needs? This requires us to comprehend and describe the consumers' demand, and explain the mechanism that causes this kind of demand. In this paper, we use consumption theory and econometric method to analyze empirically individual consumer's food safety perception and consumption in Tianjin city. Our aim is

\footnotetext{
* Institute of Economics, Faculty of Economics, Nankai University, China
} 
to illustrate the characteristics of individual consumers' food safety perception and consumption behavior, and to analyze how individual consumer attributes affect the food safety perception and consumption behavior.

\section{FORMER ECONOMIC STUDY ON FOOD SAFETY}

Relevant economic study on food safety began in 1970's; however, the public began to pay extensive attention to the food safety and health just from 1980's. From then, many governments and public groups gradually began to pay attention to it. Scholars began to do detailed analysis on consumers' demand aspect including consumers' perception of the risks, and how statistic data affect consumers to get information on food safety, the relation of income and food safety risk, and food demand behavior. The most typical researcher is Katherine Clancy (1986), who primarily analyzed the consumer's reaction to the public policy.

In 1987 in Food Marketing Policy Center of Connecticut University, an individual strategy, public policy and food system performance project, a regional research project NE-165 was established to do food safety research systematically. And in 1990 the outcome of the above project was published as a book titled Economics of Food Safety. That book brought up the theory and method of how to measure the consumers' demand reaction, and it also did a detailed research in the safety information aspect of the consumers' individual characteristics of education level, and how income level affects their ability of accepting information and applying risk information. Moreover, John M. Antle (1995) also did a deep research of food safety policy.

In Japan, consumers began to pay attention to food safety when it entered into 1980 's, and research started then too. Since 1990's, a research team led by S. Kai published in succession some research fruits, including the international comparison of food safety systems, GMO, organic food etc. The team brought up that the competition of food production and processing changed from production costs to food safety, and food safety time was approaching.

The research of food safety economics started after the appearance of green food in China. Most of the researches are the papers released by leaders and scholars in some meetings and papers. They (Liu1998, Li1997) expatiated mostly the importance of food safety on the whole, and suggested developing thoughts by comparing China with other developed countries in policy system. Moreover, Xie Min et al. (2002) analyzed the management system of food safety theoretically. However, all the researches didn't do an empirical analysis to the individual consumer's food safety reaction in China.

This paper is the first time to analyze and explain the individual consumers' food safety reaction in China. This paper includes many factors of economy, society, and education and so on affecting food safety choice. The paper uses consumer theory to get results that enrich the researches in this field.

\section{ANALYSIS FRAME AND DATA DESIGN}

How to handle consumption information becomes an important factor to increase people's welfare in the complicated and changing market. Individual consumer's choice of 
food safety is the important manifestation of consumer's handling consumption information. In U. S., among the 10 major factors that cause death, there are 5 factors relates to food consumption (U.S. Surgeon General 1988). It's very important to handle the consumer's consumption information. However, we have little information about how individual attributes affect consumer's perception and understanding of food safety.

On the economics, it's not a new subject that individual attributes affect consumption information demand and consumption behavior. Schultz (1975) emphasized that education was important to influence individual to obtain information and consumption. Becker (1972) drew a conclusion that the family's economic ability was a notable decisive factor to acquire information and individual consumption. Grossman (1972) discussed that the different individual health conditions influence the acquiring of new safety information. The development and suggestion of the above standpoints and the related theories may have many different influence factors in the obtaining of individual safety information.

In the traditional consumption analysis of microeconomics, income and price are the main factors to affect consumption decision. However, individuals' living environment (cultural, social factors and so on) and attributes are not ignored factors to analyze food consumption (katayama 1996). Therefore, in this study, we try to analyze individual consumer demand of food safety from the view of consumer's living environment.

Table 1. Variables defined in the food safety decision model.

\begin{tabular}{|c|c|c|}
\hline & Value & Definition \\
\hline Perception degree of food safety & $0-1$ & Careless of $=0$, concern $=1$ \\
\hline Whether to know green food & $0-1$ & Don't know $=0$, know $=1$ \\
\hline If bought green food & $0-1$ & Have never bought $=0$, bought $=1$ \\
\hline If know GMO food & $0-1$ & Don't know $=0$, know $=1$ \\
\hline If want to purchase GMO food & $0-1$ & Don't want to purchase $=0$, want to purchase $=1$ \\
\hline Gender & $0-1$ & Female $=0$, male $=1$ \\
\hline Age & $1-4$ & $\begin{array}{l}20 \text { years old below }=1,20-39 \text { years old }=2, \\
40-59 \text { years old }=3,60 \text { years old or above }=4\end{array}$ \\
\hline Monthly salary & $1-4$ & $\begin{array}{l}499 \mathrm{RMB} \text { below }=1,500-999 \mathrm{RMB}=2, \\
1000-1999 \mathrm{RMB}=3,2000 \mathrm{RMB} \text { or } \text { above }=4\end{array}$ \\
\hline Educational background & $1-5$ & $\begin{array}{l}\text { Elementary School }=1 \text {, junior high } \\
\text { school }=2 \text {, senior high school }=3 \text {, } \\
\text { university }=4 \text {, the graduate student or above }=5\end{array}$ \\
\hline Living environment & $0-1$ & Village $=0$, city $=1$ \\
\hline Work circumstance & $1-3$ & $\begin{array}{l}\text { Have no work }=1 \text {, half day work }=2 \text {, } \\
\text { whole day work }=3\end{array}$ \\
\hline If smoke cigarette & $0-1$ & Smoke cigarette $=0$, not smoke cigarette $=1$ \\
\hline If take the vitamin & $0-1$ & Not take $=0$, take $=1$ \\
\hline
\end{tabular}

This paper regards Tianjin City as analysis object. Data analysis uses the materials from the questionnaire investigated by Nankai University Yunneng Venture Club members in Anshanxi Road Carrefour Supermarket in Tianjin City in April 2002. They investigated 289 individual consumers by random sampling survey.

This paper analyzes food safety choice to explain quantitatively how individual consumer's attributes affect food safety choice and the causality between these variables. In this paper, we use educational background, monthly salary, and the fact whether or not 
to take vitamin, to represent the individual's education level, income and health condition, respectively. Before using food safety choice model to analyze the main reasons affecting food safety choice, it's necessary to quantify the variables. The variables are defined in Table 1 above.

\section{ANALYSIS OF ATTRIBUTES AFFECTING INDIVIDUALS' FOOD SAFETY CONSUMPTION BEHAVIOR}

In existing studies, many kinds of econometric models are used to analyze the consumer's demand and grasp the causal relation of consumption behavior. In this paper, according to the former definitions, the perception degree of food safety (Careless of $=0$, concern=1), if know green food (Don't know=0, know=1), if bought green food (Have never bought=0, buy=1), if know GMO food (Don't know=0, know=1) and if want to purchase GMO food (Don't want to purchase $=0$, want to purchase $=1$ ) is binary variables, so the linear regressive model can't be used to explain the relation of these variables. There are many kinds of methods available for the analysis of data when the dependent variables are binary variables, one of which, the probit model, that is extensively used to analyze the binary variables as an important probability model in social and economic study.

In this paper, the probit model is used to analyze the dependent variables. Here, this analysis is a probability analysis when each of the four dependent variables equals 1 . The probit model is as follows. At first, we may assume the following linear model.

$$
\text { (1) } A_{i}=b+\sum_{j=1}^{k} c_{j} x_{i j}+u \text {, }
$$

In which $\mathrm{Ai}$ is a latent variable. What we get in practice is its binary variable $\mathrm{a}_{\mathrm{i}}$ and $\mathrm{a}_{\mathrm{i}}=1$ when $\mathrm{Ai}>0, \mathrm{a}_{\mathrm{i}}=0$ when $\mathrm{Ai} 0$. Therefore, $a_{i}$ is binary variables of the four dependent variables, which stand for perception degree or consumption tendency, respectively.

In probit model, the error $\mathrm{u}$ is supposed to follow standard normal distribution, the formula is

$$
\text { (2) } F\left(a_{i}\right)=\int_{-\infty}^{z i} \frac{1}{\sqrt{2 \pi}} \exp \left(\frac{-t^{2}}{2}\right) d t \text {. }
$$

When $\mathrm{a}_{\mathrm{i}}=1$, the probability is

$$
\text { (3) } P i=F\left(b+\sum_{j=1}^{k} c_{j} x_{i j}\right) \text {. }
$$

In general case, we suppose that variance of error $u$ in equation(1) equals 1 .

In the following paragraphs, we analyze the four dependent variables and respective independent variables (characteristics of consumers). The results are described in table 2. Some of the consumers' attributes are not statistically significant when the significance level is set to $5 \%$ at single side. But, without these attributes in the model, the goodness-of-fit of the model would decrease. So these variables are still kept in the model. The following are the explanations of the dependent variables.

1. Perception degree of food safety. The significant variables are gender, monthly salary, and education background. This means that consumers who are female, high monthly 
Table 2. Analysis on main influencing attributes of individuals' food safety consumption behavior (probit regression)

\begin{tabular}{lccccc}
\hline & $\begin{array}{l}\text { if concern about } \\
\text { food safety }\end{array}$ & $\begin{array}{l}\text { if know green } \\
\text { food }\end{array}$ & $\begin{array}{l}\text { if bought green } \\
\text { food }\end{array}$ & $\begin{array}{l}\text { if know GMO } \\
\text { food }\end{array}$ & $\begin{array}{c}\text { lf want to buy } \\
\text { GMO food }\end{array}$ \\
\hline constant & -1.03495 & $-2.08163^{*}$ & 0.14973 & $-2.39441^{* * *}$ & $-1.36003^{*}$ \\
gender & $-0.60942^{*}$ & $0.57412^{*}$ & 0.02592 & $0.84714^{* * *}$ & 0.19209 \\
age & -0.01116 & 0.02881 & -1.2927 & $0.30380^{* *}$ & 0.00776 \\
monthly salary & $0.90841^{* *}$ & -0.06745 & -0.04465 & -0.08099 & $-0.22961^{* *}$ \\
education background & $0.30659^{*}$ & $0.50855^{* * *}$ & 0.04208 & $0.23871^{* *}$ & 0.15071 \\
living environment & 0.69876 & $1.13852^{* *}$ & $0.88304^{* *}$ & 0.53893 & 0.27249 \\
working circumstance & 0.01062 & -0.22844 & 0.16312 & 0.04365 & 0.03650 \\
if smoke cigarette & -0.01704 & 0.51759 & 0.28659 & $0.87085^{* * *}$ & 0.10166 \\
if take vitamin & 0.23683 & -0.10345 & $0.60026^{* * *}$ & 0.18637 & $0.42789^{* *}$ \\
\hline if concern about food safety & $0.98481^{*}$ & $-1.78090^{* *}$ & 0.58921 & $0.71521^{*}$ \\
if know green food & & & $1.12447^{* *}$ & & \\
if know GMO food & & & & & $-0.29866^{* *}$ \\
\hline Pearson Goodness-of-fit & 112.821 & 93.791 & 211.141 & 226.017 & 220.959 \\
Chi Square & 220 & 219 & 215 & 217 & 211 \\
DF & 1.000 & 1.000 & 0.562 & 0.323 & 0.305 \\
Porbobility & & & & & \\
\hline
\end{tabular}

$\cdots<1 \%, " * 5 \%,{ }^{*}<10 \%$ significance level.

salary, high education level are paying attention to the food safety problem. In which, monthly salary and education background that have a plus relation with perception degree of food safety, are key factors to affect consumer perception and their consumption behavior.

2. Perception degree of green food. The significant explanation variables are gender, education background, living environment and the perception degree of food safety. This means that male, well-educated consumers, and those who live in urban district, have a high perception degree for green food. The conclusion is that education background and living environment have strong influences on perception degree of green food. Besides, the perception degree of food safety is also positively related to perception degree of green food.

3. If bought green food. The significant explanation variables include consumer's living environment, if take vitamin. The consumers, who live in cities, and those who take vitamin frequently, have more probably ever bought green food. This result is consistent with our common sense. In the modern China, the discrimination between urban and rural affects deeply the consumption behavior. Moreover, the influencing variables have perception degree of food safety (minus correlation) and whether to know green food (plus correlation). The latter can be easily explained, the consumers who know green food are willing to buy the green food. And the former can be explained that the consumers who paid attention to food safety are prudent in buying green food, this may be a delicate reflect on the facing green food production, certification and distribution system.

4. If know GMO food. The significant variables have gender, age, education background 
and if smoke cigarette. This means that the consumers who are male, youth, and have high education level, do not smoke cigarette know green food. Especially, the more strict T-test confirms that the education background is in $1 \%$ significance level, this means that the education background have a very important influence on knowing GMO food.

5. If want to buy GMO food. The significant factors have monthly salary, If take the vitamin. It is very interesting for the consumers who have a high monthly salary, are not willing to buy GMO food. This means that they are not willing to take risks to consume GMO food, because they have comprehended the science implication of GMO food. In the other hand, 'If know GMO food' have a minus correlation with 'If want to buy GMO food', this means that the consumers who know GMO food, are not willing to consume GMO food. It shows that the consumer began to pay attention to GMO food:

\section{CONCLUDING REMARKS}

With the development of economy and the enhancing of people's living level, food demand change is being brought out in China. It is changed from pursuing food quantity to pursuing food-quality and-safety. There are an increasing number of consumers who pay attention to food-quality and-safety. By this means, consumers' perception, and consumption of food safety are thoroughly changing in China. In the stage, it is very important for theory and practice guidance to grasping and dealing with the difference of consumers' habit and preference correctly.

This paper analyzed and explained how individuals' attributes influence on the perception and consumption of food safety by an econometric model, using the questionnaire of individuals investigated in Tianjin city. The main conclusions are as follows.

1. Female consumers with higher monthly salary and higher education level have higher perception degree of food safety. In which, the positive influence of monthly salary and education level is consisted with the above analysis and former research presented in the paper's preface. We can conclude that monthly salary and education level have important influences on the perception degree of food safety and the two attributes are very important factors to determinate individuals' perception of food safety.

2. The male consumers with higher education level and residing in urban know green food. It can be concluded that the degree of perception is strongly influenced by education level and inhabitation. : The consumers who live in city and usually take vitamin can buy more green food. This is consisted with our common sense. In current China, the difference of urban and rural directly influenced on the consumption behavior. In addition, the perception degree of food safety has a negative influence on whether consumers buy green food. This can be explained that consumer care more about food safety, he/she is more cautious in purchasing green food. It may be a subtle change of consumer's psychology in the primary stage of production and certification and sale of green food.

3. Male and young consumers with higher education level and not smoking know GMO food. The education level is an important variable to determinate whether people know GMO food. The higher the monthly income consumers have, the less they buy GMO food. These maybe conclude that, they have understood GMO food correctly and will 
not choice risky food in food consumption.

Based this above analysis, we can bring forward such policy suggestion as follows. With the enforcement of economic reform, the economy has been developing greatly and the people's income has enhanced much, so food consumption has quite mushroomed in China. However, China is still in the period of developing economics, the difference of urban-rural, education and income, which formed in past long time, restrict individuals' perception and consumption of food safety. So, it is necessary to eliminate the difference of urban-rural thoroughly and make everyone equality to receive primary education, easy to have a higher educational chance and establish a rational and fair income distribution system, in order to promote individual consumer' welfare.

\section{REFERENCES}

Gray S. Becker 1977 The Economic Approach to Human Behavior University of Chicago Press, Chicago, pp. 23-28

John M. Antle 1995 Choice and Efficiency in Food Safety Policy. The AEI Press, Washington, D. C., pp. 1-109

Julie A. Caswell (ed.) 1991 Economics of Food Safety Elsevier Science Publishing Co. Inc., pp. 3-27

Katayama Takao 1996 Economic Analysis of Consumption. Keisoshobo, Tokyo, pp. 3-5

Katherine Clancy (ed.) 1986 In Consumer Demands in the Market Place: Public Policies Related to Food Safety, Quality and Human Health. Resources for the Future, Washington, D. C., pp. 55-73

Li Lite 2001 Organic Agriculture and Green Food, Study on Agricultural Sustainable Development in China, pp. 15-35

Liu Lianfu (ed.) 1998 Instruction of Green Food, Publishing Company of Corporation Management, pp.15-26

Michael Grossman 1972 On the Concept of Health Capital and the Demand for Health. Journal of Political Economy, 80: 223-255

Satoshi Kai (ed.) 1999 International Comparative Study on Quality Safeguard of Meat Food Production and Distribution. Under A Grant-in-Aid for international Sciences Research (Field Research) submitted to The Ministry of Education, Science, Sports and Culture of Japan, pp. 1-12

Theodore W. Schultz 1975 The Value of the Ability to Deal with Disequilibria. Journal of Literature, 13: $827-846$

U. S. Surgeon General 1998 The Surgeon General's Report on Nutrition and Health. U. S. Department of Health and Human Services, Public Health Service, U. S. Government Printing Office, Washington, D. C., pp. 28-43

Xie Min, Yu Yongda 2000, Analysis on Food Safety in China, Joumal of Shanghai Economic Research, 1: $39-45$ 